\title{
Sekurytyzacja aktywów na przykładzie kryzysu „subprime” w Stanach Zjednoczonych
}

Asset securitization based on the example of the subprime crisis in the United States

\section{Wstęp}

Sekurytyzacji zaczęto poświęcać więcej uwagi za sprawą kryzysu subprime w Stanach Zjednoczonych, mimo iż instrument ten był od dłuższego czasu powszechnie stosowany przez banki. Wraz z zachodzącym procesem globalizacji rozpoczęła się transformacja tradycyjnego modelu bankowości opartego stricte na przyjmowaniu depozytów i udzielaniu kredytów, ponieważ rozwijające się rynki kapitałowe zaczęly stanowić atrakcyjniejsze miejsce dla finansowania potrzeb przedsiębiorstw. Rosnąca konkurencja oraz presja na obniżanie kosztów finansowania sprawiły, że instytucje finansowe, takie jak banki, oferowały warunki postrzegane jako mniej atrakcyjne. Spowodowało to zmiany zarówno na rynkach kapitałowych, jak i w systemie bankowym, które przyczyniły się do rosnącej popularności sekurytyzacji, co szczególnie było widoczne w latach przed kryzysem subprime.

W niniejszym artykule został poruszony temat sekurytyzacji aktywów na przykładzie kryzysu subprime w Stanach Zjednoczonych w latach 2007-2008. Podjęto próbę kompleksowego ujęcia zagadnienia w aspekcie teoretycznym na podstawie publikacji krajowych oraz zagranicznych. W pierwszej części przedstawiono teoretyczne aspekty sekurytyzacji aktywów, z naciskiem na pokazanie sposobu, w jaki są tworzone struktury sekurytyzacyjne. W kolejnej części zaprezentowano, jak wygląda oddziaływanie tego instrumentu w ujęciu systemowym na przykładzie kryzysu subprime. Następnie dokonano oceny sekurytyzacji na podstawie doświadczeń płynących z kryzysu finansowego w Stanach Zjednoczonych. Skala załamania na rynku oraz jego skutki skłoniły 
Autora do kompleksowego zaprezentowania zagadnienia, jakim jest sekurytyzacja aktywów, i potwierdzenia, że mimo nieprawidłowości, jakie miały miejsce w USA, proces ten przynosi wiele korzyści i stanowi istotny element $\mathrm{w}$ dalszym rozwoju rynków, szczególnie w obszarze zarządzania ryzykiem kredytowym oraz płynnością (dywersyfikacja źródeł finansowania).

\section{Sekurytyzacja jako instrument finansowy}

W literaturze przedmiotu sekurytyzację definiowano jako emisję papierów wartościowych, które zabezpieczano przepływami pieniężnymi pochodzącymi z aktywów, przy zachowaniu warunku jednoczesnego usunięcia ich z bilansu inicjatora (banku). W późniejszym okresie zaczęto określać ją jako metodę finansowania polegającą na transformacji mniej płynnych aktywów w papiery wartościowe, które następnie sprzedawano na rynku (Balcerowicz-Szkutniak i in., 2009). W Rozporządzeniu Parlamentu Europejskiego i Rady (UE) sekurytyzacja natomiast jest definiowana jako transakcje lub program, w wyniku których ryzyko kredytowe związane z ekspozycją lub pulą ekspozycji podlega podziałowi na transze. W rzeczywistości proces ten postrzega się nie tylko jako sposób na pozyskanie środków, lecz także jako metodę zarządzania ryzykiem poprzez możliwość jego transferu z bilansu na inne podmioty.

Andreas Jobst definiuje sekurytyzację jako metodę wykorzystywaną przez banki, pozwalającą im na transfer ryzyka, którego odbiorcami są w głównej mierze firmy ubezpieczeniowe, fundusze hedgingowe czy inne banki. Powodem wykorzystywania przez instytucje tego instrumentu finansowego jest przede wszystkim dążenie do uzyskania tańszego kosztu pozyskania środków na dalszą działalność oraz zwolnienie kapitału regulacyjnego (Jobst, 2008).

Według Dova Solomona sekurytyzację można określić jako proces stanowiący metodę refinansowania działalności, pozwalającą bankom jako inicjatorom na użycie aktywów znajdujących się w bilansie i generujących przewidywalne przepływy pieniężne na pozyskanie finansowania (Solomon, 2012). Poprzez wyizolowanie aktywów i ich sekurtyzację podmioty przeprowadzające ten proces są w stanie pozyskać znacznie niżej oprocentowany kapitał aniżeli poprzez pożyczanie zabezpieczone aktywami. Wydzielane aktywa, będące różnego rodzaju wierzytelnościami w bilansie inicjatora, są następnie sprzedawane do wyspecjalizowanego podmiotu nazywanego spółką specjalnego przeznaczenia (Special 
Purpose Vehicle - SPV1), która zajmuje się sekurytyzacją aktywów. Spółka ta po nabyciu od inicjatora aktywów wykorzystuje je do emisji walorów nazywanych ABS (asset-backed securities), otrzymane zaś środki od inwestorów przekazuje inicjatorowi, który następnie w celu uregulowania zobowiązań z tytułu emisji wobec inwestorów dokonuje upłynnienia aktywów.

Istotną kwestią w przypadku procesu sekurytyzacji wydaje się być sam fakt, jakie aktywa mogą zostać poddane sekurytyzacji. W tym przypadku wskazuje się następujące kryteria, które powinny zostać spełnione:

- możliwość wyceny i wiarygodne określenie wartości pieniężnej,

- jednorodna oraz wystarczająco duża pula aktywów.

Jako przykład podaje się kredyty hipoteczne lub innego rodzaju wierzytelności $\mathrm{z}$ naciskiem na fakt, że aktywa te muszą być odpowiednio zdywersyfikowane przed przeprowadzeniem procesu w celu uniknięcia kumulacji ryzyka. Ponadto sekurytyzacją mogą być objęte zarówno wierzytelności już powstałe, jak i przyszłe. Mimo szerokiego zastosowania instrumentu, jakim jest ten proces, wciąż jest on wykorzystywany głównie przez same banki w celu lepszego zarządzania portfelem kredytowym. Kryteria odnośnie do aktywów, które mogą zostać poddane sekurytyzacji, muszą spełniać poniższe warunki:

- Jednorodność aktywów (np. stała stopa oprocentowania o tej samej wysokości).

- Pozytywna ocena inicjatora procesu pod kątem dokładności przy przeprowadzaniu procesu (jakość nadzorowania i zarządzania aktywami).

- Istnienie danych historycznych odnośnie do aktywów w banku będącym inicjatorem.

- Obowiązujące regulacje zezwalające na transfer aktywów poza bilans inicjatora.

- Możliwość uzyskania większej jakości kredytowej od instytucji z wysokim ratingiem i wiarygodnością.

Aktywa podlegające sekurytyzacji generują stałe przepływy pieniężne i w zależności od struktury oraz typu dzielone są na różnego rodzaju transze. Środki trafiają do inwestorów w odpowiedniej kolejności, co wynika bezpośrednio ze struktury emisji. Jako pierwsze wypłacane są transze typu senior (charakteryzujące się najniższym ryzykiem), na końcu zaś o profilu z wyższym ryzykiem (transza equity). W momencie, kiedy nie dochodzi do przepływów pieniężnych z aktywów bazowych, następuje default, czyli niewypłacalność kredytobiorcy, oraz obniżenie

${ }^{1} \mathrm{SPV}$ jest jednostką specjalnie tworzoną na potrzeby przeprowadzenia procesu - zajmuje się zarządzaniem strukturą przepływów pieniężnych pochodzących z aktywów bazowych oraz zapewnia jej płynności, tak aby inwestorzy regularnie otrzymywali część odsetkową i kapitałową przepływów. 
wysokości poszczególnej transzy. W tym przypadku w pierwszej kolejności transza equity „absorbuje” straty i jest pomniejszona o wysokość utraconych przepływów pieniężnych, w następnej mezzanine, a na końcu transza senior. Podkreśla się, że na ogół bardziej ryzykowne transze typu equity i mezzanine pozwalają bez problemu na zaabsorbowanie strat powstałych na skutek niewypłacalności przepływów z aktywów bazowych portfela (International Monetary Fund, 2009). Podział transz z tytułu sekurytyzowanych aktywów dokonuje się pod kątem stóp zwrotu oraz ryzyka, które jest szacowane oraz wyceniane przez agencje ratingowe. Najwyższej oceniane są transze senioralne (rating $\mathrm{AAA}^{2}$ ), natomiast typu equity, czyli dające najwyższą stopę zwrotu, ale i najbardziej ryzykowne z reguły nie posiadają ratingu. Na poniższym schemacie przedstawiono przykładową strukturę sekurytyzacji oraz rozłożenie transz w jej ramach.

Schemat 1. Przykład struktury sekurytyzacyjnej

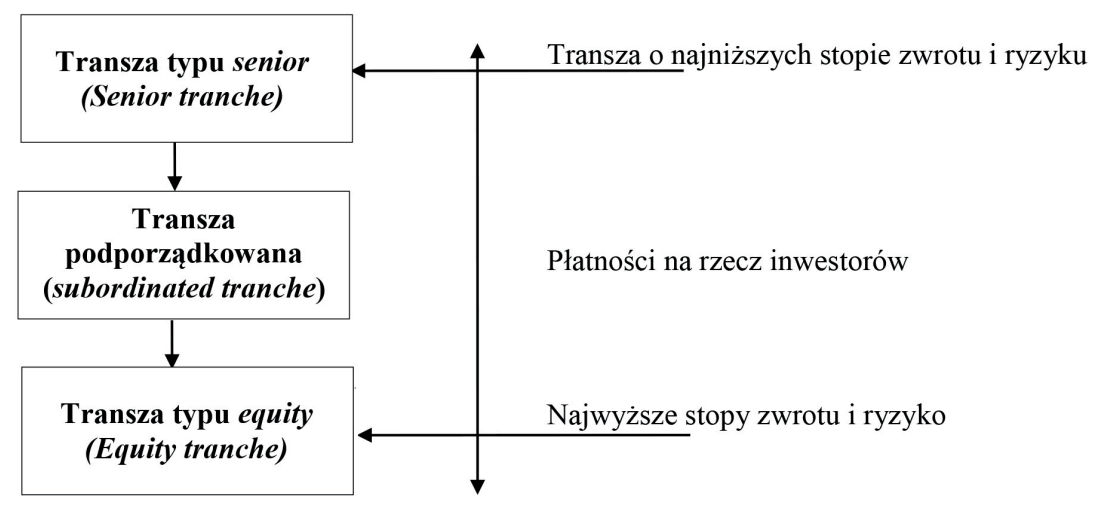

Źródło: Opracowanie własne na podstawie Report to the Congress on risk retention, Federal Reserve Board, October 2010.

Proces sekurytyzacji wymaga udziału - oprócz samego inicjatora - także innych podmiotów, które posiadają wąską specjalizację pozwalającą tym samym na jego prawidłowe przeprowadzenie i maksymalizację płynących z niego korzyści. W literaturze wymienia się sześć kluczowych podmiotów, które biorą udział w procesie. W pierwszej kolejności wskazuje się inicjatora samego procesu (zazwyczaj bank), który udziela kredytów oraz je obsługuje, czyli zbiera płatności i pilnuje, aby pożyczkobiorcy wywiązywali się ze swoich zobowiązań, a także stara się, aby inwestorzy nabywający papiery wartościowe zabezpieczone tymi

${ }^{2}$ Zob. FitchGroup, https://www.thefitchgroup.com/site/poland/definitions. 
wierzytelnościami przez cały okres ich trwania mieli odpowiednią ochronę przed defaultem (Kendall, Fishman, 2000). Ponadto inicjatorami procesu sekurytyzacji mogą być - oprócz instytucji finansowych - zupełnie inne podmioty, np. przedsiębiorstwa, które prowadzą działalność w różnych gałęziach gospodarki. Kolejnym krokiem jest sprzedaż wyodrębnionych aktywów bilansowych (wierzytelności) spółce specjalnego przeznaczenia (SPV), która na ich podstawie dokonuje emisji papierów wartościowych.

Kolejnym podmiotem zaangażowanym w proces sekurytyzacji aktywów jest agent emisyjny, bezpośrednio zajmujący się sprzedażą papierów wartościowych utworzonych przez SPV, którego głównym celem jest zachęcanie potencjalnych nabywców do kupna walorów oraz minimalizacja kosztów samej emisji. W tym przypadku agent jest odpowiedzialny za strukturę transzy i przyporządkowanie aktywów do jednej z nich w zależności od tego, jaką dają stopę zwrotu, z jakim ryzykiem się wiążą oraz jaki jest ich termin zapadalności. Ponadto decyduje on o formie samej emisji, czy ma być dostępna dla każdego inwestora (emisja publiczna), czy tylko dla wybranych podmiotów (prywatna), tak aby znalazł się zbyt na wyemitowane papiery wartościowe.

W proces sekurytyzacyjny zaangażowany jest także powiernik (określany również jako doradca), który przede wszystkim reprezentuje interesy inwestorów i pełni rolę administratora trustu (zazwyczaj w takiej formie zakładana jest SPV). Jego zadaniem jest odpowiednia dystrybucja i kalkulacja strumieni płatności generowanych przez aktywa bazowe należnych inwestorom, którzy nabyli sekurytyzacyjne papiery wartościowe, a także zapewnienie płynności całej struktury, aby istniał regularny przepływ środków pieniężnych aż do terminu zapadalności. Powiernik jednocześnie musi dokonać wszelkich niezbędnych czynności w celu zapewnienia odpowiedniej jakości zabezpieczenia (aktywów bazowych). Istotną czynnością jest również monitorowanie regularnego wywiązywania się podmiotów, które są stronami w procesie, co dotyczy w głównej mierze samego inicjatora. Powiernik w zakresie swoich obowiązków współpracuje z podmiotem serwisującym wierzytelności, przekazującym mu raporty odnośnie do samych aktywów oraz płatności pochodzących z nich.

Szczególną rolę w procesie pełnią ratingi nadawane przez agencje ratingowe, których celem jest przede wszystkim wiarygodne przedstawienie informacji oraz danych związanych z ryzykiem wyemitowanych papierów sekurytyzacyjnych. Przyznane ratingi dają możliwość oceny inwestorom prawdopodobieństwa wystąpienia problemów z wypłacaniem środków i jakości samych aktywów. W momencie, kiedy emisja ma charakter publiczny, warunkiem koniecznym jest uzyskanie takiego ratingu w celu zapewnienia przejrzystości samej struktury emisji. 
W proces sekurytyzacji zaangażowane są także podmioty zapewniające wsparcie dla jakości kredytowej aktywów bazowych w celu ochrony inwestorów przed sytuacją, w której środki generowane przez aktywa nie są w stanie pokryć części kapitałowej i odsetkowej transzy. Wsparcie jakości portfela kredytowego stanowiącego zabezpieczenie jest wykorzystywane w celu poprawy ratingu kredytowego dla emitowanych papierów wartościowych. Wsparcie kredytowe na ogół jest zapewniane poprzez udzielenie akredytywy lub poręczenia i na ogół podmiotami dającym takie gwarancje są banki lub przedsiębiorstwa ubezpieczeniowe $z$ wysokim ratingiem. Oprócz akredytywy i gwarancji poprawa jakości kredytowej może zostać zapewniona poprzez założenie gotówkowego rachunku zabezpieczającego służącego na zakup krótkoterminowych papierów wartościowych z wysoką oceną (ratingiem) za środki z udzielonego kredytu bankowego. Zarówno w roli gwaranta, jak i podmiotu zapewniającego płynność (poprzez założony rachunek) całej struktury przez czas jej funkcjonowania występuje duża instytucja finansowa.

Schemat 2. Podstawowa struktura procesu sekurytyzacyjnego aktywów

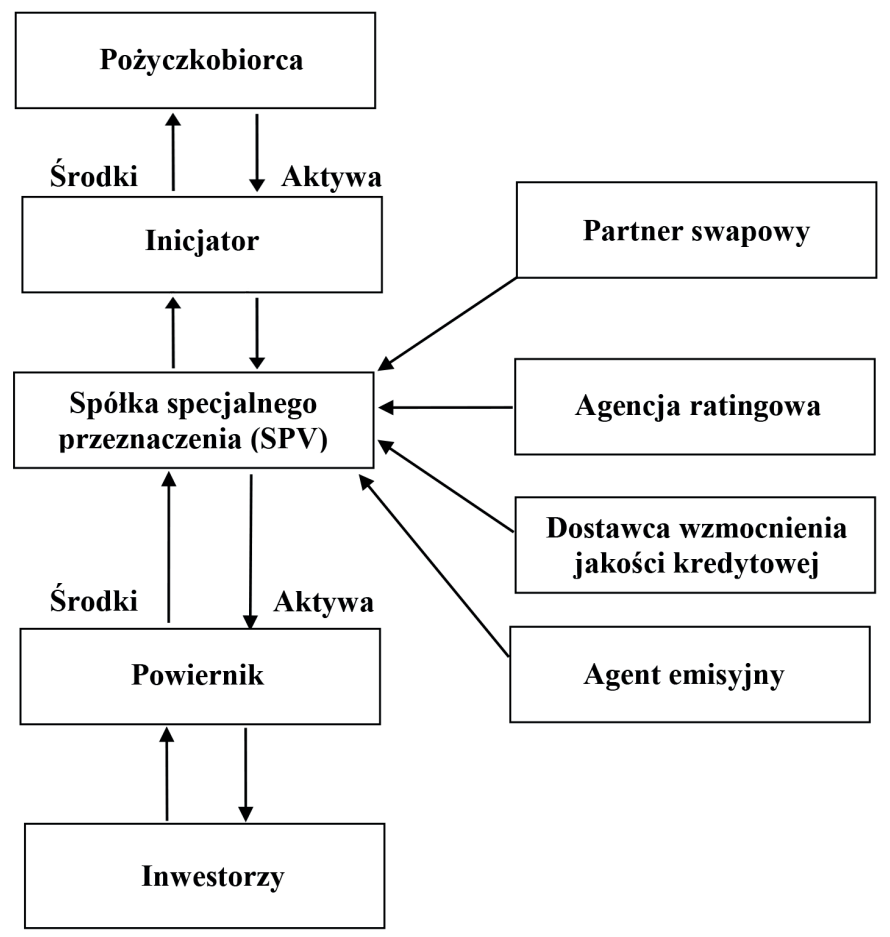


Z punktu widzenia ryzyka procesu warto wspomnieć o uczestniczeniu w tej strukturze partnera swapowego, którego rolą jest przejęcie określonego typu ryzyka, jakim jest obarczona sekurytyzacja (niekorzystna zmiana danego parametru ekonomicznego, np. ryzyko niewypłacalności) w zamian za ustaloną opłatę. Transfer ryzyka najczęściej dokonywany jest przy użyciu takich instrumentów pochodnych jak IRS (Interest Rate Swap) czy CDS (Credit Default Swap; w przypadku transferu ryzyka kredytowego). Kontrakt swapowy na stope procentową $\mathrm{w}$ tym przypadku polega na zawarciu dwustronnej umowy pomiędzy SPV a partnerem swapowym, który zobowiązany jest do wymiany strumieni pieniężnych liczonych według zmiennej stopy na liczone według stałej stopy procentowej lub na odwrót. Jako przykład podaje się sytuację, w której bank z aktywów bazowych (z udzielonych kredytów) otrzymuje płatności odsetkowe według stałej stopy procentowej, kupony zaś z wyemitowanych papierów są płacone według zmiennego oprocentowania, co w przypadku wzrostu rynkowych stóp powoduje niedobór środków na spłacenie zobowiązań wobec inwestorów, dlatego zawierany jest kontrakt swapowy IRS w celu zabezpieczenia tego ryzyka.

Liczba zaangażowanych podmiotów w sekurytyzację aktywów oraz stosowane instrumenty finansowe pokazują złożoność samego procesu, który w głównej mierze polega na umiejętnym zarządzaniu ryzykiem, czyli jego rozproszeniu pomiędzy uczestników całej struktury. Ponadto należy zaznaczyć, że jednostki zaangażowane $\mathrm{w}$ proces $\mathrm{z}$ reguły są wyspecjalizowanymi podmiotami, które mają ściśle określone obowiązki i współpracują między sobą w celu utrzymania jak największej przejrzystości sekurytyzacji.

\section{Sekurytyzacja, a kryzys „subprime” w latach 2007-2009}

Wydarzenia na rynku amerykańskim miały specyficzny przebieg ze względu na unikalny charakter tamtego rynku finansowego, niemniej jednak pokazały, że sekurytyzacja może mieć wpływ w wymiarze systemowym. Szczególnie istotnym faktem w tym przypadku była sama jakość aktywów bazowych (kredytów) opartych na segmencie subprime $e^{3}$, stanowiących zabezpieczenie w znaczącej ilości emitowanych papierów sekurytyzowanych. Mimo że sam proces z punktu

\footnotetext{
${ }^{3}$ Segment subprime dotyczył kredytów udzielanych osobom o bardzo niskiej zdolności kredytowej określanych również jako NINJA (no income, no job, no assets). Przed wybuchem kryzysu banki na szeroką skalę udzielały kredytów bez przeprowadzenia odpowiedniej weryfikacji kredytobiorców, którzy często nie posiadali odpowiednich źródeł dochodów.
} 
widzenia instytucji finansowych, takich jak banki, miał charakter pozytywny, ponieważ miały one stały dostęp do finansowania oraz możliwość generowania zysków poprzez zwiększanie akcji kredytowej, to był jednym z wielu powodów powstania niskich standardów w udzielaniu kredytów. Należy również podkreślić, że przyczynił się on do wzrostu efektywności całego systemu finansowego nie tylko w wymiarze alokacji i rozproszenia ryzyka pomiędzy uczestników rynku, lecz także korzystania z samego kapitału.

W literaturze zarówno sekurytyzacja, jak i powstałe zawirowania na rynku były skutkiem implikacji modelu originate-to-distribute, czyli wykorzystania możliwości przez banki sprzedawania udzielonych pożyczek na rynku kapitałowym w postaci papierów wartościowych. Idea samego modelu nie była zła, jednak sposób jego oddziaływania w wymiarze systemowym wraz z kumulacją szeregu innych czynników przesądziły o tym, że w 2007 r. doszło do załamania się rynku sekurytyzowanych papierów wartościowych opartych na segmencie subprime. Przeprowadzanie samego procesu sekurytyzacji przez banki było niewłaściwe pod względem jego przejrzystości, zarówno dla organów nadzoru, jak i inwestorów, ponieważ złożoność procesu była na tyle duża, że powodowało to problem z identyfikacją potencjalnych ryzyk. Ponadto kilka lat przed kryzysem inwestorzy wskazywali, że największym problemem w przypadku sekurytyzacji aktywów jest jej niska przejrzystość.

Skomplikowane struktury sekurytyzacyjne kreowane przez amerykańskie banki utrudniały możliwość oszacowania i kwantyfikacji ryzyka, powodując, że obiektywna wycena papierów wartościowych powstałych przy wykorzystaniu tego instrumentu finansowego była wyjątkowo ciężka, a wręcz momentami niemożliwa. Ponadto spadek przejrzystości był spowodowany w pewnym stopniu stosowaniem arbitrażu regulacyjnego, co wiązało się zarówno z korzyściami dla banków, jak i negatywnymi konsekwencjami dla systemu finansowego. W przypadku sekurytyzacji opierało się to w głównej mierze na transferze ryzyka między poszczególnymi podmiotami przy wykorzystaniu kredytowych instrumentów pochodnych. Instytucje finansowe będące inicjatorami procesu podczas kryzysu przy transferze ryzyka korzystały $\mathrm{z}$ różnic $\mathrm{w}$ reżimach regulacyjnych danych państw, co stwarzało dodatkowe zagrożenie o znacznie szerszym zasięgu. Mimo że arbitraż regulacyjny nie był głównym powodem stosowania sekurytyzacji podczas kryzysu, to nie może być on bagatelizowany, gdyż różnice regulacyjne związane $\mathrm{z}$ wymogami kapitałowymi mogą stanowić istotny impuls przy stosowaniu tego instrumentu w wymiarze negatywnym z perspektywy stabilności finansowej (Basel Committee on Banking Supervision, 2011). W tym przypadku sekurytyzacja daje możliwość transferu ryzyka kredytowego na podmioty, które 
nie są w stanie efektywnie nim zarządzać lub też nie mają odpowiedniej bazy kapitałowej. Jednocześnie należy wskazać, iż może to prowadzić do efektu rozmycia i zniekształcenia mapy przepływu ryzyka w systemie finansowym, powodując duże prawdopodobieństwo jego trafienia do segmentu instytucji nieobjętych regulacjami. W celu uniknięcia tych negatywnych skutków postuluje się stworzenie zintegrowanego systemu regulacyjnego oraz wprowadzenie jednolitych standardów ograniczających możliwość wykorzystywania arbitrażu regulacyjnego (Niedziółka, 2011).

Zjawisko moral hazard (pokusy nadużycia) miało miejsce podczas kryzysu subprime w odniesieniu do samego procesu sekurytyzacji, nie tylko podczas udzielania kredytów osobom z niższymi dochodami, ale i przy sprzedaży toksycznych aktywów opartych na tych kredytach przez rynek kapitałowy. Kolejnym faktem było nagminne korzystanie z możliwości transferu ryzyka na inne podmioty pod tym względem, że po przeprowadzeniu procesu sekurytyzacji złej jakości wierzytelności inicjatorzy (banki) nie dokładali starań, aby kontynuować dalsze monitorowanie portfela kredytowego po usunięciu z bilansu ryzyk. Sekurytyzacja pozwoliła instytucjom podejmować nadmierne ryzyko i jednocześnie maksymalizować zyski przy wykorzystaniu efektu skali, w rezultacie prowadząc do transferu znaczącej ilości ryzyka na rynek, powodując jego nadmierną koncentrację.

Podczas kryzysu miała miejsce korelacja między pokusą nadużycia a wykorzystywaną przy procesie sekurytyzacji asymetrią informacji, która w znacznej mierze była efektem niskiej przejrzystości papierów wartościowych opartych na segmencie subprime. W latach przed załamaniem się rynku tych papierów panowało przekonanie o wyjątkowej atrakcyjności tych walorów nie tylko ze względu na wysokie stopy zwrotu, ale i na samo ich zabezpieczenie portfelem wierzytelności oraz wysokim ratingiem nadawanym przez uznane agencje ratingowe. W momencie załamania okazało się, że inwestorzy nie posiadali odpowiednich informacji i wiedzy na temat wierzytelności, które miały stanowić zabezpieczenie, oraz ryzyka związanego z tymi aktywami.

Według Frederica Mishkina korzyści płynące z procesu sekurytyzacji były dostrzegane poprzez uczestników rynku, jak i organy regulacyjne, niemniej jednak ewentualne problemy powstające przed kryzysem bagatelizowano lub też nie do końca rozumiano. Wskazuje on, że ten instrument finansowy nie funkcjonował poprawnie pod tym względem, że nie kreował on w latach przed kryzysem żadnych zachęt do odpowiedniego przeprowadzania procesu oraz utrzymywania odpowiedniej jakości wierzytelności. Sekurytyzacja natomiast stwarzała bodźce do emisji opartej nie na jakości, lecz na ilości przeprowadzo- 
nych emisji, które pozwalały uzyskiwać wysokie dochody inicjatorom kosztem długoterminowej wypłacalności tych papierów wartościowych (Mishkin, 2008).

Barry Eichengreen w swoim raporcie o stabilności finansowej z 2008 r. wskazuje, że mimo kryzysu kredytowego i restrykcyjnych regulacji wprowadzanych przez organy nadzorcze niepożądanym efektem byłaby kompletna eliminacja sekurytyzacji z rynków, gdyż wiąże się ona z korzyściami dla całego systemu finansowego. W kontekście kryzysu z 2007-2009 r. sekurytyzacja nie jest wskazywana jako główny powód załamania rynku, uwaga zaś powinna być skierowana na sam system bankowy. Według Eichengreena banki nadal odgrywają kluczową rolę, ich słabości zaś należy definiować poprzez sam system safety net, który mimo swojej ważnej dla stabilności funkcji może w ostateczności stwarzać również niepożądane efekty, takie jak zjawisko pokusy (Eichengreen, 2008).

Zdarzenia z 2007 r. na rynku amerykańskim pokazały, iż sekurytyzacja jest procesem złożonym i zależnym od wielu czynników, które mogą mieć istotny wpływ na poprawność jego działania. Pojawiają się również wnioski, iż podczas kryzysu subprime za załamanie się rynku w głównej mierze były odpowiedzialne wątpliwej jakości aktywa zabezpieczające emitowane papiery wartościowe, czyli wierzytelności związane z segmentem hipotecznym. Mimo tych nieprawidłowości na rynku amerykańskim sekurytyzacja jest instrumentem, który wiąże się z wieloma korzyściami i przy odpowiednich regulacjach może być z powodzeniem stosowany z korzyścią zarówno dla instytucji finansowych, inwestorów, jak i całego systemu finansowego.

\section{Ocena procesu sekurytyzacji aktywów w kontekście kryzysu finansowego w USA}

Doświadczenia płynące z kryzysu subprime pokazują, że na początku sekurytyzacja wymaga zrozumienia jej zasad działania zarówno przez uczestników rynku, jak i przez same podmioty inicjujące ten proces, co jest warunkiem koniecznym w celu uzyskania stabilnego rozwoju tego segmentu. Brak nadzoru i przejrzystości procesu oraz sama jego złożoność, a także niewłaściwe zachęty dla inicjatorów emisji sekurytyzacyjnych papierów wartościowych stały się kluczowymi problemami na rynku amerykańskim w 2008 r. Jednocześnie należy wskazać, iż definitywna eliminacja tych problemów w przyszłości będzie ściśle związana z tym, jak będzie nadzorowany obszar instytucji finansowych.

Mimo nadużyć, jakie miały miejsce podczas kryzysu, należy wskazać, że sekurytyzacja wiąże się z wieloma korzyściami, takimi jak zwiększenie ela- 
styczności w zakresie zarządzania ryzykiem. Pozwala ona przede wszystkim na dekoncentrację ryzyka w bilansie takich instytucji jak banki oraz systemie finansowym, a tym samym jego lepszą dywersyfikację. Innym ważnym aspektem w tym przypadku jest również dostęp do bardziej zróżnicowanych źródeł finansowania, obniżenie ryzyka płynności, a także przyczynienie się do łagodniejszych cykli kredytowych oraz zmniejszenie prawdopodobieństwa wystąpienia krachów kredytowych. W wymiarze całego systemu efektywna alokacja ryzyka pomiędzy uczestnikami rynku jest istotnym czynnikiem wpływającym na zwiększenie efektywności rynków, gdyż jego dywersyfikacja i rozproszenie może przyczyniać się do większej stabilności finansowej.

Kolejnym istotnym aspektem jest jej rola w zakresie pozyskiwania finansowania, czyli możliwość stosowania w przypadku przyszłych wierzytelności,

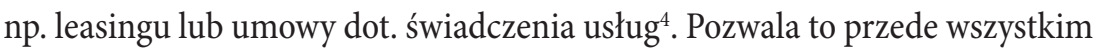
podmiotom z państw mniej rozwiniętych na pozyskiwanie kapitału po niższym koszcie oraz daje dostęp do zagranicznego finansowania. Oprócz tego sekurytyzacja jest bardzo dobrym rozwiązaniem dla państw charakteryzujących się niższym poziomem rozwoju, by mogły one pozyskać finansowanie na rynkach międzynarodowych (sekurytyzacja przyszłych wpływów). Należy w tym przypadku wskazać w szczególności na niższy koszt kapitału oraz zaletę, jaką jest dostęp do finansowania z rynków, szczególnie w sytuacji kryzysu płynnościowego lub w momencie podwyższonej percepcji ryzyka danego kraju (obniżenie ratingu kredytowego).

Z uwagi na elastyczność w kwestii wierzytelności, jakie można sekurytyzować, należy spojrzeć na ten instrument jako przydatny z perspektywy samorządów oraz finansowania ich budżetów poprzez sekurytyzację dochodów municypalnych. Strumienie pieniężne do obsługi długu generowane mogą być z bieżących lub przyszłych wpływów, w tym dochodów uzyskiwanych ze zrealizowanych w przyszłości inwestycji. Możliwość pozyskiwania środków na przeprowadzenie projektów inwestycyjnych wydaje się ciekawym rozwiązaniem, gdyż ułatwia realizowanie istotnych celów oraz zarządzanie płynnością. W przypadku jednostek samorządu możliwość wykorzystania tego procesu musi wiązać się z przeprowadzeniem szczegółowych prognoz związanych z przyszłą sytuacją demograficzną, jak i efektywnością wykorzystania środków z emisji. Przykład ten pokazuje, że instrument finansowy, jakim jest sekurytyzacja, należy pozytywnie ocenić ze

${ }^{4}$ Przykładem może być przeprowadzona w 2019 r. przez PKO Leasing jedna z największych na rynku transakcji sekurytyzacji aktywów o wartości 2,5 mld zł, której celem była dywersyfikacja źródeł finansowania oraz zmniejszenie kosztów ryzyka kredytowego przy jednoczesnej redukcji obciążeń kapitałowych. 
względu na to, że pozwala uwolnić środki na realizacje projektów przy jednoczesnym braku wzrostu zadłużenia, co jest ciekawą alternatywą dla tradycyjnych źródeł finansowania, takich jak kredyt czy emisja obligacji. W momencie utraty zdolności kredytowej samorządy poprzez przeprowadzenie sekurytyzacji mogą sobie zapewnić płynność na obsługę bieżących wydatków przy jednoczesnej redukcji kosztów zadłużenia ${ }^{5}$.

Sekurytyzacja również pozwala na dostarczenie inwestorom papierów wartościowych o stosunkowo wysokiej stopie zwrotu, w momencie gdy dochodowość innych instrumentów w dobie niskich stóp procentowych jest niewielka. Pozwala to też na elastyczne kształtowanie struktury portfela i jego dywersyfikację pod kątem profilu ryzyk ze względu na oferowaną dużą rozpiętość stóp zwrotu oraz ryzyka. Z drugiej strony jest to instrument, który zapewnia płynność oraz daje znaczne możliwości takim instytucjom jak banki na swobodne kształtowania własnej struktury portfela oraz zarządzania kapitałem regulacyjnym.

Sektor firm ubezpieczeniowych może być również jednym z beneficjentów tego instrumentu, jeśli chodzi o transfer różnego rodzaju ryzyka, jak np. wystąpienie ryzyka katastrof naturalnych. W tej sytuacji podmioty te mogą dokonywać emisji obligacji, które w razie katastrofalnych wydarzeń zapewniają im płynność lub rekompensatę w przypadku poniesionych strat. Tak więc można dostrzec, iż nie tylko w sektorze bankowym sekurytyzacja może znaleźć zastosowanie, lecz także w innych segmentach rynku, gdzie może mieć ona znaczący wpływ i pozytywnie oddziaływać na jego efektywność oraz możliwość rozproszenia ryzyka.

Mimo że sekurytyzacja przyczynia się do zwiększenia złożoności systemu finansowego, to autor ocenia ją pozytywnie, ponieważ wpływa na wzrost efektywności tego systemu w zakresie dywersyfikacji ryzyka oraz płynności dla uczestników rynku w postaci alternatywnych źródeł finansowania. Krytyka, jakiej został poddany po kryzysie ten instrument finansowy - zdaniem autora - nie do końca była uzasadniona, a wszelkie nieprawidłowości, które mu przypisywano, były efektem w głównej mierze złego nadzoru regulacyjnego oraz wynikającego z tego zjawiska pokusy nadużycia. Kluczowymi elementami, od których zależeć będzie, czy sekurytyzacja zostanie z powodzeniem zaimplementowana w przyszłości, są przede wszystkim czynniki stricte związane z przejrzystością procesu, czyli dostępnością informacji na temat emisji, a także odpowiednimi zachętami

${ }^{5}$ Ze względu na duży stopień skomplikowania, wymaganą liczbę podmiotów zaangażowanych w cały proces oraz brak dotychczasowego doświadczenia w stosowaniu sekurytyzacji samorządy w Polsce do tej pory nie korzystały z tej możliwości pozyskiwania finansowania. Innym czynnikiem, jaki się tutaj wskazuje, jest brak przejrzystego otoczenia prawnego, które jasno definiowałoby, na jakich zasadach można by stosować sekurytyzację aktywów. 
i bodźcami dla zarządzających podmiotami zaangażowanymi w proces sekurytyzacji 6 . Implementacja takich zmian w tym obszarze stanowi duże wyzwanie, niemniej jednak należy podkreślić, że przy właściwym ich wdrożeniu można się spodziewać, iż segment produktów strukturyzowanych będzie spełniał właściwą rolę w kontekście całego systemu finansowego.

\section{Zakończenie}

Kryzys finansowy w Stanach Zjednoczonych w latach 2007-2008 pokazał, że sekurytyzacja jako instrument finansowy stosowany na szeroką skalę przez instytucje finansowe ma znaczenie o wymiarze systemowym. Niewłaściwy nadzór regulacyjny oraz warunki zachęcające do powstawania zjawiska pokusy nadużycia mogą sprawić, że sekurytyzacja zamiast zwiększać efektywność rynków poprzez dywersyfikację ryzyka oraz obniżenie kosztu finansowania, może prowadzić do istotnych problemów o wymiarze systemowym. Mimo to należy podkreślić, iż jest to instrument finansowy, który z powodzeniem będzie mógł być w przyszłości stosowany, ponieważ wiąże się z wieloma korzyściami oraz pełni ważną funkcję w zakresie dywersyfikacji ryzyka, obniżenia kosztów finansowania oraz zwiększenia dostępności i atrakcyjności papierów wartościowych dla inwestorów. Niezależnie od tego, jak do tej pory była oceniana sekurytyzacja aktywów, nie ulega wątpliwości, iż instrument ten będzie pełnił bardzo ważną rolę w dalszym rozwoju rynków ze względu na jego szeroką skalę zastosowań.

\section{Streszczenie}

Załamanie na rynku kredytów hipotecznych w Stanach Zjednoczonych rozpoczęło się w 2007 r. i było pod względem skali oraz skutków jednym z najbardziej dotkliwych zarówno dla rynków finansowych, jak i jego uczestników. Wykorzystywana inżynieria finansowa (sekurytyzacja) przez instytucje finansowe do tworzenia papierów wartościowych opartych na kredytach hipotecznych z segmentu subprime doprowadziła do efektu zarażania, powodując upadek instytucji o znaczeniu systemowym. Celem niniejszego artykułu jest zaprezentowanie sekurytyzacji oraz potwierdzenie, że mimo negatywnych doświadczeń płynących z kryzysu należy pozytywnie ocenić ten instrument finansowy, głównie ze względu na jego istotną rolę w zwiększeniu efektywności rynków finansowych. W pierwszej części zaprezentowano działania sekurytyzacji oraz jakie podmioty są w nią

${ }^{6}$ W 2019 r. wprowadzono istotne zmiany dotyczące sekurytyzacji aktywów - z dniem 1 stycznia weszła poprawka do dyrektywy CRD IV określana jako „Capital Requirements Regulation Amendment”, która w pełni reguluje kwestię sekurytyzacji na poziomie UE i tworzy przejrzyste ramy prawne oraz standardy zachęcające uczestników rynku do stosowania tego instrumentu. 
zaangażowane. Następnie skoncentrowano się na pokazaniu zdarzeń, jakie miały miejsce w USA w latach 2007-2009 oraz jaką rolę w tym wszystkim odgrywał proces sekurytyzacji aktywów. Na koniec przeprowadzono analizę samego instrumentu finansowego poprzez pryzmat kryzysu subprime, na podstawie której dokonano jego oceny.

SŁOWA KLUCzOWE: sekurytyzacja, kryzys subprime, ryzyko kredytowe, zarządzanie płynnością.

\section{Summary}

The collapse of the US mortgage market began in 2007 and was one of the most severe in terms of scale and impact on both financial markets and its participants. The financial engineering (securitization) used by financial institutions to create securities based on subprime mortgages led to a contagion effect, causing systemic institutions to collapse. The purpose of this article is to present the asset securitization process and to confirm that despite the negative experience stemming from the subprime crisis, this financial instrument should be assessed positively, mainly due to its considerable role in increasing the efficiency of financial markets. The first part describes how securitization works and which entities are involved in it. Then the author focuses on showing the events that took place in the US in 2007-2009 and presenting the role the asset securitization process played in all of this. Finally, an analysis of the financial instrument itself is conducted through the prism of the subprime crisis on the basis of which it was assessed.

KEYWORDS: securitization, subprime, credit risk, liquidity management.

\section{Bibliografia}

\section{Akty prawne}

Rozporządzenie Parlamentu Europejskiego i Rady (UE) 2017/2401 z dnia 12 grudnia 2017 r. zmieniające rozporządzenie (UE) nr 575/2013 w sprawie wymogów ostrożnościowych dla instytucji kredytowych i firm inwestycyjnych, Dz.Urz. UE L 341/1.

\section{Literatura}

Balcerowicz-Szkutniak, M., Lawędziak, B., Szkutniak, W., Wolny-Dominiak, A., Zakrzewska-Derylak, B. (2009). Ryzyko zobowiazań i działań w inwestycjach gospodarczych oraz ubezpieczeniowych. Aspekt modelowania i oceny sekurytyzacji ryzyka. Katowice: Wydawnictwo Akademii Ekonomicznej w Katowicach.

Basel Committee on Banking Supervision. (2011). Report on asset securitisation incentives. Basel: Bank for International Settlements.

Bąk, J. (2007). Charakterystyka podmiotów uczestniczących w procesie sekurytyzacji aktywów - ich funkcje i powiązania. Gospodarka Surowcami Mineralnymi, 3, 52. 
Chrabonszczewska, E., Waszkiewicz, A. (2010). Ryzyko na międzynarodowych finansowych. Warszawa: Wydawnictwo KGŚ.

Credit where credit's due. The rating industry has bounced back from the financial crisis. (2014). The Economist, 19.04.2014. Pobrano z: https://www.economist. com/finance-and-economics/2014/04/19/credit-where-credits-due (08.06.2020).

Deloitte. (2018). Securitization. Structured finance solution. Pobrano z: https://www2. deloitte.com/content/dam/Deloitte/lu/Documents/financial-services/lu_securitization-finance-solutions.pdf (04.09.2020).

Eichengreen, B. (2008). Ten questions about subprime crisis. Financial Stability Review: Special issue Liquidity, 11, 18.

Federal Deposit Insurance Corporation. (1998). Securitizations. W: Managing the crisis: The FDIC and RTC Experience (s. 410). Washington D.C.: Federal Deposit Insurance Corporation.

Green, R., Wachter, S., (2007). The housing finance revolution. W: S. J. Smith, B. A. Searle (Eds.), Housing, Housing Finance, and Monetary Policy (s. 38-59). Kansas City: Federal Reserve Bank of Kansas City.

Gudkova, S. (2002). Sekurytyzacja należności kredytowych banków. Warszawa: Wydawnictwo Wyższej Szkoły Przedsiębiorczości i Zarządzania im. Leona Koźmińskiego.

HSBC. (2020). The European Securitisation market in 2020:Navigating uncharted territories, 16 July 2020, s. 4-8. Pobrano z: https://www.gbm.hsbc.com/insights/ capital-financing/the-european-securitisation-market-in-2020 (04.09.2020).

Haładyj, K. (2007). Sekurytyzacja - potrzeba zmian. Przeglad Prawa Handlowego, 3, 43-50.

Hałaburda, D. (2016). Sekurytyzacja jako forma finansowania jednostek samorządu terytorialnego. Ekonomiczne Problemy Usług, 125, 175-185.

International Monetary Fund. (2009). Restarting Securitization markets: Policy proposals and pitfalls. W: Global Financial Stability Report. Navigating the Financial Challenges Ahead (s. 80-81). Washington DC: IMF Multimedia Service Device.

Jastrzębska, M. (2009). Zarządzanie długiem jednostek samorządu terytorialnego. Warszawa: Wydawnictwo Wolter Kluwer Polska.

Jobst, A. (2008). What is securitization? Back to basics. Finance \& Development, 45(3), 48.

Kendall, L., Fishman, M. (1996). A Primer on Securitization. Cambridge: The MIT Press.

Ketkar, S., Ratha, D. (2005). Recent Advances in Future Flow Securitization. The Financier, $11 / 12,8$.

Kreczmańska-Gigol, K. (red.). (2015). Płynność finansowa przedsiębiorstwa. Warszawa: Wydawnictwo Difin.

Martin, J. (2009). A Primer on the Role of Securitization in the credit market crisis of 2007. Texas: Baylor University. 
Mishkin, F. (2008). On Leveraged Losses: Lessons from the Mortgage Meltdown. New York: Proceedings of the US Monetary Policy Forum.

Moody's Investors Service. (2019). Structured finance - China. Securitization continues to grow as a funding source for the economy, with RMBS leading the way. Pobrano z: https://structuredfinance.org/wp-content/uploads/2019/06/Securitization_funding_Chinese_economy_Moodys_2019.pdf (20.07.2020).

Mikutowski, M. (2020). Sekurytyzacja nie tylko dla banków, 27 maja. Pobrano z: https:// cmt-advisory.pl/artykuly-eksperckie/sekurytyzacja-nie-tylko-dla-bankow/ (17.06.2020).

Nastorowicz, E. (2013). Wierzytelności w funduszach sekurytyzacyjnych działających na rynku polskim. Bezpieczny Bank, 1, 8-9.

Nawrot, W. (2009). Globalny kryzys finansowy XXI wieku - Przyczyny, przebieg skutki, progonzy. Warszawa: CeDeWu.

Niedziółka, P. (2008). Pokusa nadużycia w działalności kredytowej banków a stabilność finansowa. Bank i Kredyt, 11, 22-25.

Niedziółka, P. (2011). Kredytowe instrumenty pochodne a stabilność finansowa. Warszawa: Oficyna Wydawnicza SGH.

OECD. (1999). Trends and Developments in Securitisation. OECD Financial Market Trends, 74, 47-53.

Office of the Comptroller of the Currency. (1997). Asset Securitization. Comptroller's Handbook. Washington D.C.: Comptroller of the Currency.

Pawłowski, M. (2018). The revival of the Securitization Market after the Global Financial Crisis: A Case of Europe. Ekonomiczne Problemy Ustug, 4, 29-37.

PricewaterhouseCoopers. (2020). Securitisation in Luxembourg - A comprehensive guide. Luxemburg: PwC Luxemburg.

Rapkiewicz, M. (2013). Skąd wziąć dodatkowe pieniądze na inwestycje?, 6 sierpnia. Pobrano z: https://www.portalsamorzadowy.pl/prawo-i-finanse/skad-wziac-dodatkowe-pieniadze-na-samorzadowe-inwestycje,51163.html (27.07.2020).

Reksa, Ł. (2004). Sekurytyzacja wierzytelności na rynkach międzynarodowych. Bank i Kredyt, 2, 66.

Riddiough, T. (2010). Can Securitization Work? Economic, structural, and policy considerations. The Journal of Portfolio Management, 37, 24-38. doi: 10.3905/ jpm.2011.37.5.024

Schwarcz, S. (2009). The future of securitization. Connecticut Law Review, 41(4), 1325-1334.

Sławiński, A. (2007). Przyczyny i konsekwencje kryzysu na rynku papierów wartościowych emitowanych przez fundusze sekurytyzacyjne. Bank i Kredyt, 8-9, 14-16.

Sobolewski, P. (2014). Wiśniewski: sekurytyzacja sposobem na niższe finansowanie. Parkiet. Gazeta Giełdy, 14 maja. Pobrano z: https://www.parkiet.com/Gospodarka- 
-i-Finanse/305149782-Wisniewski-sekurytyzacja-sposobem-na-nizsze-finansowanie.html?preview=\&remainingPreview=\&grantedBy=preview\& (29.07.2020).

Solomon, D. (2012). The rise of giant: Securitization and the global financial crisis. American Business Law Journal, 49(4), 1-2.

Waszkiewicz, A. (2011). Ryzyko sekurytyzacji a kryzys finansowy. Warszawa: Oficyna Wydawnicza SGH.

Zombrit, J. (2002). Sekurytyzacja w świetle bankowych regulacji europejskich. Warszawa: SGH.

\section{Nota o autorze}

Aleksander Stuglik - mgr, absolwent Szkoły Głównej w Warszawie na kierunku Finanse i Rachunkowość; główne obszary działalności naukowej rynki kapitałowe, analiza finansowa spółek; e-mail: aleksanderstuglik@gmail.com. 